\title{
High species richness of native pollinators in Brazilian tomato crops
}

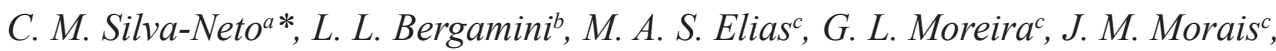 \\ B. A. R. Bergamini ${ }^{b}$ and E. V. Franceschinelli ${ }^{a}$ \\ a'Departamento de Botânica, Instituto de Ciências Biológicas, Universidade Federal de Goiás - UFG \\ Campus Samambaia, CP 131, CEP 74001-970, Goiânia, GO, Brazil \\ ${ }^{\text {b} D e p a r t a m e n t o ~ d e ~ E c o l o g i a, ~ I n s t i t u t o ~ d e ~ C i e ̂ n c i a s ~ B i o l o ́ g i c a s, ~ U n i v e r s i d a d e ~ F e d e r a l ~ d e ~ G o i a ́ s ~-~ U F G, ~}$ \\ Campus Samambaia, CP 131, CEP 74001-970, Goiânia, GO, Brazil \\ 'Instituto de Ciências Biológicas, Universidade de Brasília - UnB, Campus Darcy Ribeiro, \\ Bloco E, Asa Norte, CEP 70910-900, Brasília, DF, Brazil \\ *e-mail: carloskoa@gmail.com
}

Received: October 26, 2015 - Accepted: May 4, 2016 - Distributed: August 31, 2017

(With 3 figures)

\begin{abstract}
Pollinators provide an essential service to natural ecosystems and agriculture. In tomatoes flowers, anthers are poricidal, pollen may drop from their pore when flowers are shaken by the wind. However, bees that vibrate these anthers increase pollen load on the stigma and in fruit production. The present study aimed to identify the pollinator richness of tomato flowers and investigate their morphological and functional traits related to the plant-pollinator interaction in plantations of Central Brazil. The time of anthesis, flower duration, and the number and viability of pollen grains and ovules were recorded. Floral visitors were observed and collected. Flower buds opened around $6 \mathrm{~h} 30$ and closed around $18 \mathrm{~h} 00$. They reopened on the following day at the same time in the morning, lasting on average 48 hours. The highest pollen availability occurred during the first hours of anthesis. Afterwards, the number of pollen grains declined, especially between $10 \mathrm{~h} 00$ to $12 \mathrm{~h} 00$, which is consistent with the pollinator visitation pattern. Forty bee species were found in the tomato fields, 30 of which were considered pollinators. We found that during the flowering period, plants offered an enormous amount of pollen to their visitors. These may explain the high richness and amount of bees that visit the tomato flowers in the study areas. The period of pollen availability and depletion throughout the day overlapped with the bees foraging period, suggesting that bees are highly effective in removing pollen grains from anthers. Many of these grains probably land on the stigma of the same flower, leading to self-pollination and subsequent fruit development. Native bees (Exomalopsis spp.) are effective pollinators of tomato flowers and are likely to contribute to increasing crop productivity. On the other hand, here tomato flowers offer large amounts of pollen resource to a high richness and amount of bees, showing a strong plant-pollinator interaction in the study agroecosystem.
\end{abstract}

Keywords: agroecosystem, buzz pollination, Exomalopsis, poricidal anther, Solanum lycopersicum L.

\section{Alta riqueza de espécies de polinizadores nativos em plantações Brasileiras de tomateiro}

\section{Resumo}

Polinizadores fornecer um serviço essencial para os ecossistemas naturais e para agricultura. Em tomateiros, as anteras são poricidas e o pólen pode sair a partir dos poros quando as flores são agitadas pelo vento. No entanto, as abelhas que vibram as anteras aumentam a carga de pólen no estigma e na produção de frutos. O presente estudo teve como objetivo identificar a riqueza dos polinizadores das flores de tomate e investigar suas características morfológicas e funcionais relacionadas com a interação planta-polinizador em plantações do Brasil central. Foram registrados o tempo de antese, duração flor, bem como o número e viabilidade de grãos de pólen e óvulos. Os visitantes florais foram observados e coletados. Os botões florais abriram-se em torno $06 \mathrm{~h} 30$ e fechou em torno de $18 \mathrm{~h} 00$. As flores reabrem no dia seguinte ao mesmo tempo na parte da manhã, com longevidade média de 48 horas. A maior disponibilidade de pólen ocorreu durante as primeiras horas da antese. Depois disso, o número de grãos de pólen diminuiu, especialmente entre as $10 \mathrm{~h} 00$ às $12 \mathrm{~h} 00$, o que é consistente com os padrões de visitação de polinizadores. Quarenta espécies de abelhas foram encontradas nos campos de tomate, 30 das quais foram consideradas polinizadores. Durante o período de floração, as plantas oferecem enorme quantidade de pólen para os seus visitantes. Isto pode explicar a alta riqueza e quantidade de abelhas que visitam as flores de tomate nas áreas de estudo. O período de disponibilidade e redução de pólen durante todo o período do dia é sobreposto com o período de alimentação das abelhas, o que sugere que elas são altamente eficazes na remoção de grãos de pólen das anteras. Muitos desses grãos provavelmente são depositados no estigma 
da mesma flor, levando à auto-polinização e o desenvolvimento de frutos. Abelhas nativas (Exomalopsis spp.) são polinizadores efetivos de flores de tomate, podendo contribuir para o aumento da produtividade das culturas. Por outro lado, as flores de tomate oferecem grandes quantidades de pólen de recursos para uma alta riqueza e quantidade de abelhas, que mostram um estudo forte interação planta-polinizador nos agroecossistemas.

Palavras-chave: agroecossistema, polinização por vibração, Exomalopsis, antera poricida, Solanum lycopersicum L.

\section{Introduction}

Pollinators provide an essential service to the ecosystem and bring many benefits to society through their role in food production and agriculture, and the conservation of biological diversity. Commonly, the reduced fruit production or deformed fruits are due to insufficient pollination and not to a lack of agrochemical input in agriculture (Silva et al., 2010). Currently, the economic value of pollinators is apparent even in crops where self-pollination occurs, such as coffee, canola and soybeans. In these cultures, a considerable increase in the production of fruits and seeds after pollination by native or introduced bees was verified (Veddeler et al., 2008). In canola, recent studies showed an increase of 55.2\% in pollinated plants (Durán et al., 2010; Rosa et al., 2011). In coffee, studies showed an increase of up to $200 \%$ in fruit yield after bee pollination (De Marco and Coelho, 2004; Ricketts et al., 2008).

Tomatoes belong to the genus Solanum (Solanaceae). Although they originated from the Andes, they have been widely cultivated around the world, including many locally adapted cultivars (Olmstead and Palmer, 1997; Chetelat et al., 2009). One of the main traits of genus Solanum is the poricidal anther dehiscence. Because of the anther morphology, the only effective pollinators are bees that vibrate the anthers to release pollen grains, in a process called buzz pollination (Buchmann and Hurley, 1978; Silva et al., 2010). Despite that cultivated varieties are autogamous, buzzing improves self-pollination, since stigmas are introrse and most of the pollen grains released from the anthers are deposited on the stigma of the same flower (King and Buchmann, 2003; Greenleaf and Kremen, 2006). The native Brazilian bee families that buzz-pollinate include Andrenidae, Apidae (except for Apis), Colletidae, Halictidae and Megachilidae (Buchmann and Hurley, 1978; Harter et al., 2002). Given the close relationship between pollinator visitation and fruit set in this crop, some of the main limiting factors for fruit formation are those influencing pollinator conservation, such as habitat loss and fragmentation, which lead to a decline in pollinator populations (Greenleaf and Kremen, 2006; Klein et al., 2007, Winfree et al., 2007).

Information about the morphological and functional traits of tomato flowers can contribute to better understanding the behavior of pollinators when collecting the pollen throughout flower development, and the consequences of this relationship for crop yield. In Central Europe, Teppner (2005) observed that large bees (Bombus) are good pollinators of tomatoes, because they can easily vibrate the anthers. In Brazil, there are studies demonstrating a direct effect of pollinators on tomato productivity in open fields (Silva-Neto et al., 2013; Deprá et al., 2014). However, there is a common belief among producers and agronomist that wind action is enough to shake the flowers causing anthers to release pollen and leading to an efficient self-pollination. The interactions between tomato flowers and native bees, and the benefits of these interactions are ignored by them. The state of Goiás is the largest tomato producer in Brazil (AGRODEFESA, 2012). However, no data are available about the pollinators' identity, species richness and interaction with the tomato flowers. Thus, the present study aimed to investigate the pollinator species richness of tomato flowers and verify their morphological and functional traits related to the plant-pollinator interaction in open tomato fields in the state of Goiás.

\section{Materials and Methods}

\subsection{Study area}

The cultivations are performed in the conventional system with the use of pesticides, being tutored crops and irrigated area with between 0.5 and 2 ha. The surroundings of the plantations usually presents fragments of native vegetation (seasonal and cerradão forests), as well as other crops (corn, pasture, cucumbers, and others). The tomato planted in the areas is the Solanum lycopersicum L. species and variety (italian DRW $3410^{\circledR}$ ).

\subsection{Pollination ecology}

The insect species that visited and pollinated tomato flowers in the region around Goiânia were surveyed in 14 fields in the municipalities of Nerópolis, Bonfinópolis, Goianápolis, Senador Canedo, Terezópolis de Goiás, Leopoldo de Bulhões and Anápolis between 06h00 to $15 \mathrm{~h} 00$ during the dry season of 2011. In each field, four rows of ca. 120 tomato plants were observed every 30 minutes. Collections were carried out three times a day over two days, for a total of three hours of sampling in each field. Each time, two persons gathered data: one in charge of bee richness data survey and another in charge of bee abundance. To estimate bee richness floral, visitors were collected using a net and killed in a killing jar. These bees were included in a pollinator collection of the Laboratory of Reproductive Biology of Plants in the Federal University of Goiás. Data on bee abundance was based on the number of bees visiting the tomato flowers. Floral visitors were observed during each visit to verify if pollen was collected by buzzing defining pollinators. A quadratic regression was used to compare the number of visitors at different times of the day. 


\subsection{Tomato floral Biology}

Both morphological and functional traits of Italian tomato flowers were investigated. One inflorescence was marked on 20 plants to observe the flower anthesis. The time and duration of flower opening within inflorescences were observed. Twenty flowers from different individuals were collected for morphometric analysis. Stigma receptivity of another 10 flowers of 10 plants was tested with $\mathrm{H}_{2} \mathrm{O}_{2}(3 \%)$ (Dafni et al., 2005; Blochtein et al., 2014). Two other flowers (first day flowers) of ten plants were collected at different times of day and fixed in FAA (1 part $40 \%$ formaldehyde to 1 part acetic acid to 8 parts $80 \%$ ethanol) to count pollen grains along the flower anthesis. Two anthers from each flower were placed on a Petri dish, mashed and stained with 5\% aceto-carmine. Pollen grains were counted in a Neubauer chamber under an optical microscope with a $10 \times$ objective lens. All pollen grains in two regions of the chamber (A and F) were counted. These numbers were added (PG), to estimate the total number of pollen grains per flower (Maêda, 1985), like the following formula: $\mathrm{NP}=(\mathrm{PG} * 2000 / 4)^{*} \mathrm{NA}$; where: NP = Number of Pollen; $\mathrm{PG}=$ Pollen Grains counted; NA = Number of Anthers.

Pollen viability was tested using the same protocol for collection, preservation, and staining of 20 flowers of 20 different individuals. After staining, a sample was placed on a slide to observe pollen viability under an optical microscope with a $40 \times$ objective lens. Pollen grains with morphological defects or those that were not stained were considered non-viable. An exponential regression was used to compare the number of pollen grains and simple linear regression to pollen viability at different times of the day (Dafni et al., 2005).

\section{Results}

\subsection{Pollinator richness}

A total of 324 individuals of 40 bee species were captured in tomato fields after 60 hours of active data collection (Table 1). All species belonged to families Apidae and Halictidae. Apidae had the greatest richness and abundance. The most common species were Exomalopsis analis (37.5\%), Augochloropsis spp. (26.1\%), Paratrigona lineata (6.7\%), Augochloropsis sp. (6.6\%), Pseudaugochlora spp. (7\%), and E. auropilosa (4.4\%). Among the 40 bee species recorded visiting flowers, Apis mellifera, Dialictus sp. (3 ssp.), Halictus sp., Frieseomellita sp., Geotrigona subterranea, Tetragonisca angustula and Tetragona sp. do not buzz pollinate. In total, there were 30 bee species with the potential to pollinate tomato flowers in the study sites (Table 1).

The total bee visits after 60 hours of observation was 1,643 , which means that 27.38 bees were observed per hour visiting tomato flowers in the sampled rows. The preliminary evaluation of the visitation dynamic of the pollinators showed that pollinator frequency varied throughout the day based on the size and behavior of the bees. Bee activity

Table 1. Bee species found in open tomato fields in the municipalities of Nerópolis, Bonfinópolis, Goianápolis, Senador Canedo, Terezópolis de Goiás, Leopoldo de Bulhões and Anápolis, Goiás State, Brazil (NP - Not pollinator; P - Pollinator).

\begin{tabular}{|c|c|c|}
\hline FAMILY & SPECIES & \\
\hline \multirow{23}{*}{ APIDAE } & Apis mellifera Linnaeus, 1758 & NP \\
\hline & Bombus morio (Swederus, 1787) & $\mathrm{P}$ \\
\hline & Centris (Hemisiella) sp. & $\mathrm{P}$ \\
\hline & Centris aenea Lepeletier, 1841 & $\mathrm{P}$ \\
\hline & Centris fuscata Lepeletier, 1841 & $\mathrm{P}$ \\
\hline & Centris tarsata Smith, 1874 & $\mathrm{P}$ \\
\hline & Centris varia (Erichson, 1848) & $\mathrm{P}$ \\
\hline & Epicharis flava Friese, 1900 & $\mathrm{P}$ \\
\hline & Epicharis sp. & $\mathrm{P}$ \\
\hline & Eulaema nigrita Lepeletier & $\mathrm{P}$ \\
\hline & Exomalopsis analis Spinola & $\mathrm{P}$ \\
\hline & Exomalopsis auropilosa Spinola & $\mathrm{P}$ \\
\hline & Exomalopsis fulvofasciata Smith, 1879 & $\mathrm{P}$ \\
\hline & Exomalopsis minor Schrottky & $\mathrm{P}$ \\
\hline & Exomalopsis sp1. & $\mathrm{P}$ \\
\hline & Exomalopsis sp2. & $\mathrm{P}$ \\
\hline & Frieseomellita sp1. & NP \\
\hline & Geotrigona subterranea (Friese) & NP \\
\hline & Melipona quinquefasciata Lepeletier, 1836 & $\mathrm{P}$ \\
\hline & Paratrigona lineata (Lepeletier) & NP \\
\hline & Tetragona $\mathrm{sp} 1$ & NP \\
\hline & Tetragonisca angustula Latreille & NP \\
\hline & Xylocopa frontalis (Olivier, 1789) & $\mathrm{P}$ \\
\hline
\end{tabular}


Table 1. Continued...

\begin{tabular}{clc}
\hline FAMILY & \multicolumn{1}{c}{ SPECIES } & $\mathrm{P}$ \\
\hline & Augochlora spp. & $\mathrm{P}$ \\
& Augochloropsis callichroa (Cockerell, 1900) & $\mathrm{P}$ \\
& Augochloropsis smithiana (Cockerell) & $\mathrm{P}$ \\
& Augochloropsis sp2. & $\mathrm{P}$ \\
& Augochloropsis sp3. & $\mathrm{P}$ \\
& Augochloropsis sp4. & $\mathrm{P}$ \\
& Augochloropsis sp5. & $\mathrm{P}$ \\
HALICTIDAE & Augochloropsis sp6. & $\mathrm{NP}$ \\
& Dialictus sp1. & $\mathrm{NP}$ \\
& Dialictus sp2. & $\mathrm{NP}$ \\
& Dialictus sp. 3 & $\mathrm{NP}$ \\
& Halictus sp1. & $\mathrm{P}$ \\
& Pseudaugochlora graminea (Fabricius, 1804) & $\mathrm{P}$ \\
& Pseudaugochlora indistincta Almeida, 2008 & $\mathrm{P}$ \\
& Pseudaugochlora sp1. & $\mathrm{P}$ \\
& Pseudaugochlora sp2. & $\mathrm{P}$ \\
\hline
\end{tabular}

started around 7h00. Only larger bees were observed early in the morning, and visitation rates peaked around $9 \mathrm{~h} 00$. Large bees (Eulaema, Bombus, Epicharis and Centris) and bees in family Halictidae had constant visitation rates throughout the day (Figures 1 and 2). In contrast, bees in the genus Exomalopsis, the most abundant in the tomato fields, initiated visitation around $9 \mathrm{~h} 00$, with a peak around $11 \mathrm{~h} 00$ and a steep decline around noon $\left(\mathrm{R}^{2}=0.40\right.$; $\mathrm{p}=0.00 ; \mathrm{y}=-4.0093 \mathrm{x} 2+46.057 \mathrm{x}-53.188 ; \mathrm{x}$ : hours of day; $\mathrm{y}$ : number of visitors).

\subsection{Plant and flower morphology}

Italian tomatoes had an herbaceous-shrubby habitat and grew up to $2 \mathrm{~m}$ in length. Plants had a short life cycle and were able to produce mature fruits in 90 to 120 days after seed germination, or in 45 to 55 days after flowering. Inflorescences were generally arranged in dichasial cymes or drepanius. Flowers were bisexual and actinomorphic, with a diameter of 1.5 to $2.0 \mathrm{~cm}$. The staminal cone was on average $1.05 \pm 0.09 \mathrm{~cm}$ long.

\subsection{Flower anthesis and viability}

Two flowers opened simultaneously in each inflorescence. Flower buds opened around 6h30, stayed open until 18h00 and then close, reopening at the same time in the following morning. Flowers took approximately one hour to open and expose the anthers. Based on an $\mathrm{H}_{2} \mathrm{O}_{2}$ test, the stigma was receptive during the entire period of anthesis. Flowers were pendulous and had open spreading petals. In the afternoon, petals became deflexed until late afternoon, when closure began (Figure 3). Most flowers last 48hs, but they may last up to 60 hours (three days).

\subsection{Number and viability of pollen grains}

Mean pollen production was $333.200 \pm 299.500$ grains per flower, with peak availability during the first hours of anthesis, between $7 \mathrm{~h} 00$ and $8 \mathrm{~h} 00$, followed by considerable

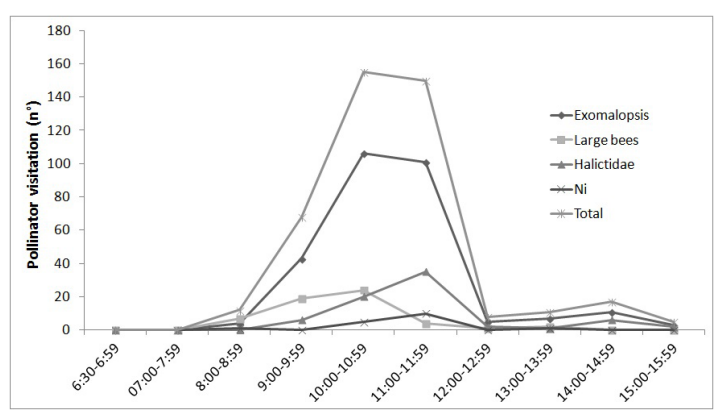

Figure 1. Number of floral visitors during the day separated into groups. The Exomalopsis group includes the total number of visits by species in the genus Exomalopsis; the large bee group includes genera Eulaema, Epicharis, Bombus, and Centris; Halictidae includes all observed species of the Halictidae family; Ni are bees not identified; and total are all bees.

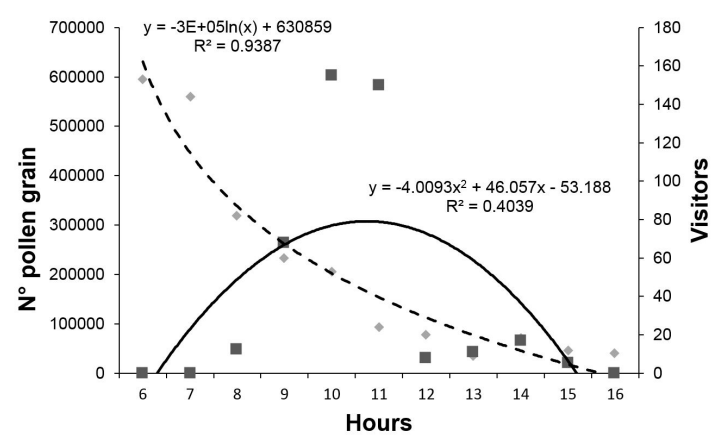

Figure 2. Number of pollen grains per flower along the flower's opening.

reduction for the rest of the day. The decline in the number of pollen grains increase around noon $\left(\mathrm{R}^{2}=0.9387\right.$; $y=-3 E+05 \ln (x)+630859 ; x$ : hours of day; $y$ : number of pollen grains) (Figure 2). This decline coincided with higher 


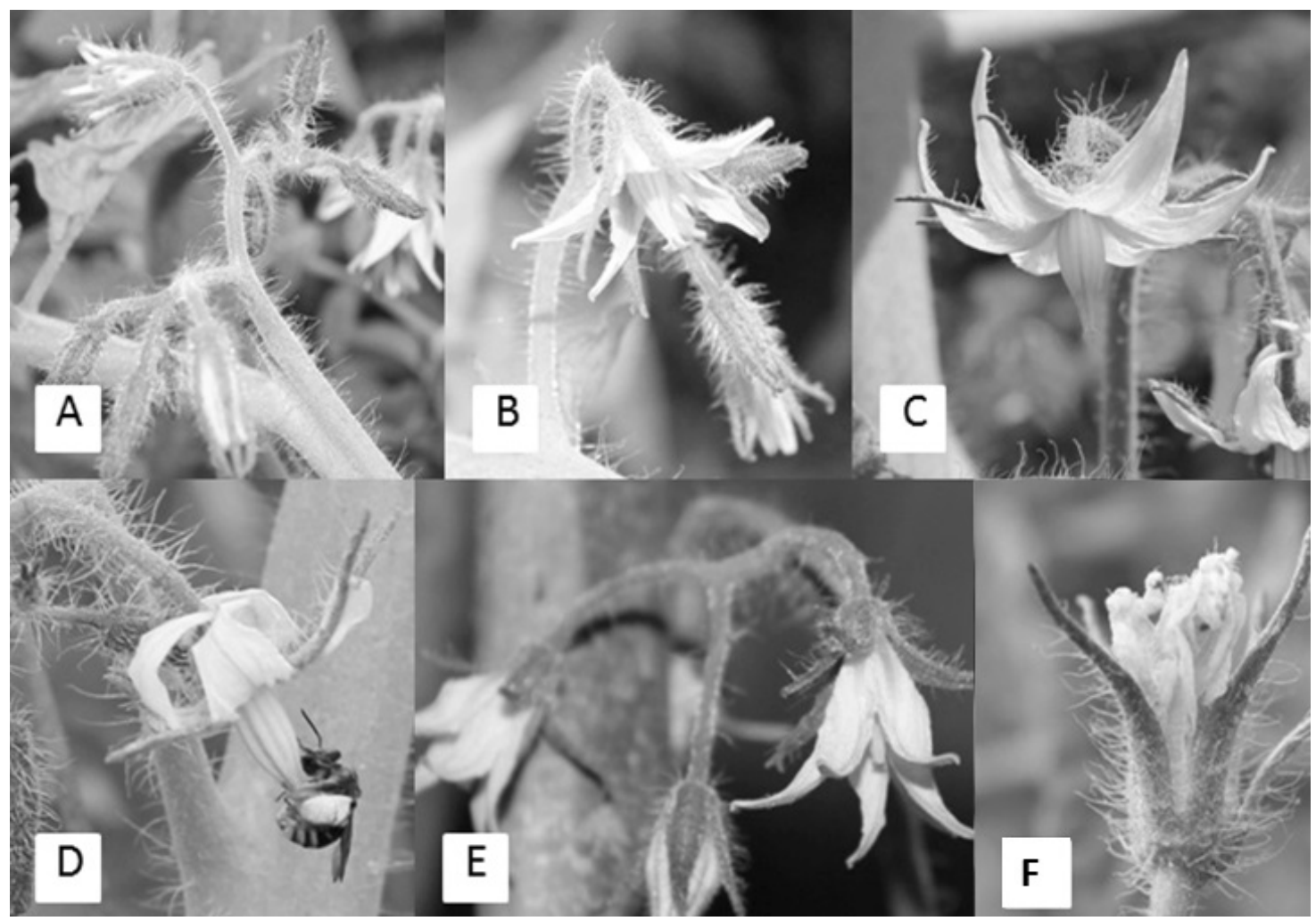

Figure 3. Tomato flower (Italian variety) (A) Onset of floral anthesis (6h30); (B) Anther presentation (7h30); (C) Deflexed petals (12h00); (D) Pollination by Exomalopsis; (E) Partial flower closure (18h00); (F) Floral senescence (third day).

visitation rates by pollinators, which were active between $7 \mathrm{~h} 00$ and $12 \mathrm{~h} 00$ and peaked around 11h00. After noon, there was a significant reduction in the number of pollen grains offered by flowers (Figure 2) and in the pollinator visitation rate (Figures 1 and 2). Pollen viability was high, with ca. $97.0 \pm 12.6 \%$ viable grains per flower, and varied during the day $\left(r^{2}=0.040 ; p=0.00 ; y=97.393-0.899 * x\right.$; $\mathrm{x}$ : hours of day, $\mathrm{y}$ : pollen viability).

\section{Discussion}

Tomato flower morphology is typical of buzz-pollinated plants (Buchmann, 1983; Forni-Martins et al., 1998; Silva et al., 2010). This is also true for other Solanum species, both cultivated (S. melongena; S. paniculatum; Montemor and Malerbo-Souza, 2005; Santos-Neto et al., 2006) and native (S. lycocarpum; S. sessiliflorum; S. stramonifolium; S. carolinense; $S$. violaceum; Oliveira-Filho and Oliveira, 1988; Storti, 1988; Bezerra and Machado, 2003; VallejoMarin and Rausher, 2007; Wanigasekara and Karunaratne, 2012). The anther cone surrounds the stigma, which is slightly below the poricidal opening of the anthers. This morphological trait is derived from the wild form, which had the stigma above the pores, establishing a herkogamous system that led to cross-pollination. Over time, as varieties became better defined, plants with stigmas below the anther openings were selected to achieve self-pollination and the conservation of selected traits (Olmstead and Palmer, 1997; Chetelat et al., 2009). However, buzz pollination is still important to fruit set for the cultivar varieties. Bee visits increase the amount of pollen on the stigma, likely improving crop productivity (Silva-Neto et al., 2013).

We found 40 bees' species visiting the tomato flowers, with 30 of them being potential pollinators. Genera Eulaema, Exomalopsis, Halictus, Augochloropsis and Pseudaugochlora are all known for buzz pollination behavior (Silva et al., 2010). Despite being able to vibrate flower anthers, $P$. lineata was not able to hold onto the tomato anthers due to its small size, collecting pollen grains previously released from the flower instead (Hoehn et al., 2008). Some of these bees are very abundant, such as Exomalopsis analis, Augochloropsis sp2. and Augochloropsis sp3. These results reveal that study plants strongly attract bee species to their flowers. Each of them had on average 35,000 tomato plants. A 50-day-old tomato (Italian cultivar) plant had on average $10.70 \pm 1.44$ inflorescences, with $7.00 \pm 2.13$ flowers per inflorescence and each flower produce per se large amounts of viable pollen grains. Then during the flowering period, these plants offered an enormous amount of pollen to their visitors. Pollen is a very important source of nutrition of bee larvae. These may explain the high diversity and amount of bees that visit the tomato flowers in the study areas, showing a strong plant-pollinator interaction in the study agro-ecosystem. 
Besides, our data clearly showed that bees respond positively to pollen availability. When this resource was abundant in the flower anthers, visitation rates were high, but decreased when the amount of pollen in the flower anthers also decreased. The peak of bee visitation to flowers occurred between $10 \mathrm{~h} 00$ to $12 \mathrm{~h} 00$ (Figures 1 and 2), especially in days with intense sunlight and low wind. This interplay between resource availability and pollinator visitation rates was also observed in other species of the genus Solanum, such as $S$. lycocarpum, S. sessiliflorum, S. stramonifolium, S. melongena, S. paniculatum, $S$. carolinense, and $S$. violaceum (Oliveira-Filho and Oliveira, 1988; Storti, 1988; Bezerra and Machado, 2003; Montemor and Malerbo-Souza, 2005; Santos-Neto et al., 2006; Vallejo-Marin and Rausher, 2007; Wanigasekara and Karunaratne, 2012).

The size of bees able to pollinate the flowers is limited by the length of the staminal tube. For instance, Dialictus sp. and Paratrigona lineata $(0.4 \mathrm{~cm}$ and $0.6 \mathrm{~cm}$ long, respectively) are not able to hold onto the staminal cone and buzz at the same time. Larger bees such as Exomalopsis spp. (0.8 cm long), in contrast, are able to grasp the staminal cone and buzz-pollinate. Exomalopsis species approached tomato flowers from the front, landing on the staminal cone. The bees grasped the cone and vibrated the anthers, releasing pollen grains that became attached to the abdomen and other body parts. Exomalopsis circled the staminal cone, buzzing repeatedly on different anthers at a time. Once its body was covered in pollen, the bee stopped buzzing and groomed itself, pushing pollen onto the corbicula (or pollen basket) (Figure 3d). This behavior was observed by other authors in other plant species (Buchmann, 1983; Bezerra and Machado, 2003; Silva et al., 2010; Santos et al., 2014).

In conventional and organic open tomato fields in the state of Sergipe (Brazil), species of genus Augochloropsis, Exomalopsis, Bombus, Centris, Dialictus, Pseudaugochlora, and Tetrapedia were considered effective pollinators (Santos and Nascimento, 2011). Species of these genera were also found in the present study, except for Tetrapedia. In addition, although Dialictus was recorded in plants of Goiás, it did not buzz-pollinate tomato anthers. Apis mellifera rarely visited tomato flowers in the study areas, probably because it cannot sonicate to remove pollen from anthers. In a few cases, A. mellifera was observed trying to gather pollen by inserting its proboscis into the poricidal opening of the anther or trying to "milk" anthers for pollen, a behavior also previously observed by other authors (Moço and Pinheiro, 1999; King and Buchmann, 2003).

Pesticides may represent a great risk to the bees that visit tomato flowers. The consequences of the indiscriminate use of many different pesticides on the study plants in regard to native pollinators have not been investigated. Pesticides may highly influence the composition, richness and abundance of bees (Van der Valk et al., 2013; Garibaldi et al., 2014). Bee diversity and abundance in the study crops could be even higher if pesticide spraying were better controlled.
A few bee species observed on tomato flowers were recorded in the state of Goiás for the first time, such as Augochloropsis callichroa Cockerell, which previously had only been observed in the state of Mato Grosso, Brazil (Moure, 2012). Likewise, all the prior records of Exomalopsis minor Schrottky (1910) were in Atlantic Forest areas in southeastern Brazil (Silveira, 2012). These new records for the state of Goiás indicate that bee species are relatively unknown in this region, and stress the importance of the linkage among agriculture, native pollinators, and native vegetation. Natural areas surrounding farms support many bee species, and their preservation may improve productivity by maintaining native pollinator populations. Several studies found that both richness and abundance of pollinators are strongly influenced by landscape composition, both in the immediate border and in more distant areas (Greenleaf and Kremen, 2006; Winfree et al., 2007; Holzschuh et al., 2008). The association of bees with native areas greatly influence flower pollination of open tomato fields, and is currently being studied by our research group.

Bee species traits such as behavior and body size can also determine their association with cultivated flowers. Small, solitary bees have a foraging area ranging from 250 to $800 \mathrm{~m}$ and tend to live near cultivated fields. In contrast, larger bees have higher flight capacity and broader foraging areas (Gathmann and Tscharntke, 2002; Hoehn et al., 2008; Holzschuh et al., 2008; Motzke et al., 2016). Important features of most bee species of our list are poorly known, such as nesting and foraging behavior. In particular, the solitary and para-social bees, which have been identified as important pollinators of many crops (e.g., in the case of culture Exomalopsis tomato and pepper) (Kremen et al., 2011; Giannini et al., 2012; Van der Valk et al., 2013; Santos et al., 2014). The knowledge about the biology of these bees is essential to implementing friendly practices for the producers of tomatoes and of other crops reliant on pollinators.

\section{Acknowledgements}

The authors are especially thankful to Conselho Nacional de Desenvolvimento Científico e Tecnológico - CNPq (National Council for Scientific and Technological Development), FAO (Food and Agriculture Organization), FUNBIO (Brazilian Fund to Biodiversity), and to the Brazilian Environment Ministry (MMA) for their funding allocation. The authors also would like to thank Coordenação de Aperfeiçoamento de Pessoal de Nível Superior - CAPES (government agency linked to the Brazilian Ministry of Education in charge of promoting high standards for post-graduate courses in Brazil) for granting a Master's scholarship to the first author. Academic English Solutions revised the English ( $<$ http://academicenglishsolutions.com/AES/home.html $>$ ).

\section{References}

AGÊNCIA GOIANA DE DEFESA AGROPECUÁRIA AGRODEFESA, 2012 [viewed 01 February 2012]. Programa de Prevenção e Controle de pragas em tomate [online]. Goiânia: AGRODEFESA. Available from: http://www.agrodefesa.go.gov.br 
BEZERRA, E.L.S. and MACHADO, I.C., 2003. Biologia floral e sistema de polinização de Solanum stramonifolium Jacq. (Solanaceae) em remanescente de mata atlântica, Pernambuco. Acta Botanica Brasiliense, vol. 17, no. 2, pp. 247-257. http:// dx.doi.org/10.1590/S0102-33062003000200007.

BLOCHTEIN, B., NUNES-SILVA, P., HALINSKI, R., LOPES, L.A. and WITTER, S., 2014. Comparative study of the floral biology and of the response of productivity to insect visitation in two rapeseed cultivars (Brassica napus L.) in Rio Grande do Sul. Brazilian Journal of Biology $=$ Revista Brasileira de Biologia, vol. 74, no. 4, pp. 787-794. http://dx.doi.org/10.1590/15196984.02213. PMid:25627587.

BUCHMANN, S.L. and HURLEY, J.P., 1978. A biophysical model for buzz pollination in angiosperms. Journal of Theoretical Biology, vol. 72, no. 4, pp. 639-657.

BUCHMANN, S.L., 1983. Buzz pollination in Angiosperms. In: C.E. JONES and R.J. LITTLE, eds. Handbook of experimental pollination biology. Brussel: Scientific and Academic Editions, $558 \mathrm{p}$.

CHETELAT, R.T., PERTUZÉ, R.A., FAÚNDEZ, L., GRAHAM, E.B. and JONES, C.M., 2009. Distribution, ecology and reproductive biology of wild tomatoes and related nightshades from the Atacama Desert region of northern Chile. Euphytica, vol. 167, no. 1, pp. 77-93. http://dx.doi.org/10.1007/s10681-008-9863-6.

DAFNI, A., KEVAN, P.G. and HUSBAND, B.C., 2005. Practical pollination ecology. Ontario: Environquest.

DE MARCO, P. and COELHO, F.M., 2004. Services performed by the ecosystem: forest remnants influence agricultural cultures' pollination and production. Biodiversity and Conservation, vol. 13 , no. 7 , pp. 1245-1255. http://dx.doi.org/10.1023/ B:BIOC.0000019402.51193.e8.

DEPRÁ, M.S., DELLAQUA, G.C.G. and GAGLIANONE, M.C., 2014. Pollination deficit in open-field tomato crops (Solanum lycopersicum L., Solanaceae) in Rio de Janeiro state, southeast Brazil. Journal of Pollination Ecology, vol. 12, pp. 1-8.

DURAN, X.A., ULLOA, R.B., CARRILHO, J.A., CONTRERAS, J.L. and BASTIDAS, M.T., 2010. Evaluation of yield component traits of honeybee pollinated (Apis mellifera L.) Rapeseed canola (Brassica napus L.). Chilean Journal of Agricultural Research, vol. 70, pp. 309-314.

FORNI-MARTINS, E.R., MARQUES, M.C.M. and LEMES, M.R., 1998. Biologia floral e reprodução de Solanum paniculatum L. (Solanaceae) no Estado de São Paulo, Brasil. Brazilian Journal of Botany = Revista Brasileira de Botanica, vol. 21, no. 2, pp. 117-124. http://dx.doi.org/10.1590/S0100-84041998000200002.

GARIBALDI, L.A., CARVALHEIRO, L.G., LEONHARDT, S.D., AIZEN, M.A., BLAAUW, B.R., ISAACS, R. and MORANDIN, L., 2014. From research to action: enhancing crop yield through wild pollinators. Frontiers in Ecology and the Environment, vol. 12, no. 8, pp. 439-447. http://dx.doi.org/10.1890/130330.

GATHMANN, A. and TSCHARNTKE, T., 2002. Foraging ranges of solitary bees. Journal of Animal Ecology, vol. 71, no. 5, pp. 757-764. http://dx.doi.org/10.1046/j.1365-2656.2002.00641.x.

GIANNINI, T.C., ACOSTA, A.L., GARÓFALO, C.A., SARAIVA, A.M., ALVES-DOS-SANTOS, I. and IMPERATRIZ-FONSECA, V.L., 2012. Pollination services at risk: bee habitats will decrease owing to climate change in Brazil. Ecological Modelling, vol. 244, pp. 127-131. http://dx.doi.org/10.1016/j.ecolmodel.2012.06.035.

GREENLEAF, S.S. and KREMEN, C., 2006. Wild bee species increase tomato production and respond differently to surrounding land use in Northern California. Biological Conservation, vol. 13, no. 1, pp. 81-87. http://dx.doi.org/10.1016/j.biocon.2006.05.025.

HARTER, B., LEISTIKOW, C., WILMS, W., TRUYLIO, B. and ENGELS, W., 2002. Bees collecting pollen from flowers with poricidal anthers in a south Brazilian Araucaria forest: a community study. Journal of Apicultural Research, vol. 40, no. 1-2, pp. 9-16. http://dx.doi.org/10.1080/00218839.2002.11101063.

HOEHN, P., TSCHARNTKE, T., TYLIANAKIS, J.M. and STEFFAN-DEWENTER, I., 2008. Functional group diversity of bee pollinators increases crop yield. Proceedings. Biological Sciences, vol. 275, no. 1648, pp. 2283-2291. http://dx.doi. org/10.1098/rspb.2008.0405. PMid:18595841.

HOLZSCHUH, A., STEFFAN-DEWENTER, I. and TSCHARNTKE, T., 2008. Agricultural landscapes with organic crops support higher pollinator diversity. Oikos, vol. 117, no. 3, pp. 354-361. http://dx.doi.org/10.1111/j.2007.0030-1299.16303.x.

KING, J. and BUCHMANN, S.L., 2003. Floral sonication by bees: mesosomal vibration by Bombus and Xylocopa, but not Apis (Hymenoptera: Apidae), ejects pollen from poricidal anthers. Journal of the Kansas Entomological Society, vol. 76, no. 2, pp. 295-305.

KLEIN, A.M., VAISSIÈRE, B., CANE, J.H., STEFFAN-DEWENTER, I., CUNNINGHAM, S.A., KREMEN, C. and TSCHARNTKE, T., 2007. Importance of crop pollinators in changing landscapes for world crops. Proceedings. Biological Sciences, vol. 274, no. 1608, pp. 303-313. http://dx.doi.org/10.1098/rspb.2006.3721. PMid:17164193.

KREMEN, C., ULLMAN, K.S. and THORP, R.W., 2011. Evaluating the quality of citizen-scientist data on pollinator communities. Conservation Biology, vol. 25, no. 3, pp. 607-617. http://dx.doi. org/10.1111/j.1523-1739.2011.01657.x. PMid:21507061.

MAÊDA, J.M., 1985. Manual para uso da câmara de Newbauer para contagem de pólen em espécies florestais. Rio de Janeiro: Universidade Federal Rural do Rio de Janeiro.

MOÇO, M.C.C. and PINHEIRO, M.C.B., 1999. Pollination ecology of Swartzia apetala Raddi var. apetala (LeguminosaePapilionoideae). Brazilian Archives of Biology and Technology, vol. 42, n. 4, p. 1-9.

MONTEMOR, K.A. and MALERBO-SOUZA, D.T., 2005. Biodiversidade de polinizadores e biologia floral em cultura de berinjela (Solanum melongena). Zootecnia Tropical, vol. 27, pp. 97-103.

MOTZKE, I., KLEIN, A.M., SALEH, S., WANGER, T.C. and TSCHARNTKE, T., 2016. Habitat management on multiple spatial scales can enhance bee pollination and crop yield in tropical homegardens. Agriculture, Ecosystems \& Environment, vol. 223, pp. 144-151. http://dx.doi.org/10.1016/j.agee.2016.03.001.

MOURE, J.S., 2012 [viewed 03 May 2013]. Augochlorini Beebe, 1925. In: J.S. MOURE, D. URBAN and G.A.R. MELO, orgs. Catalogue of bees (Hymenoptera, Apoidea) in the Neotropical Region. Curitiba: UFPR. Available from: http://www.moure. cria.org.br/catalogue

OLIVEIRA-FILHO, A.T. and OLIVEIRA, L.C.A., 1988. Biologia floral de uma população de Solanum lycocarpum St. Hill. (Solanaceae) em Lavras MG. Brazilian Journal of Botany = Revista Brasileira de Botanica, vol. 11, no. 1-2, pp. 23-32.

OLMSTEAD, R.G. and PALMER, J.D., 1997. - Implications for the phylogeny, classification and biogeography of Solanum from 
cpDNA restriction site variation. Systematic Botany, vol. 22, no. 1, pp. 19-29. http://dx.doi.org/10.2307/2419675.

RICKETTS, T., REGETZ, J., STEFFAN-DEWENTER, I., CUNNINGHAM, S.A., KREMEN, C., BOGDANSKI, A., GEMMILL-HERREN, B., GREENLEAF, S.S., KLEIN, A.M., MAYFIELD, M.M., MORANDIN, L.A., OCHIENG, A. and VIANA, B.F., 2008. Landscape effects on crop pollination services: are there general patterns? Ecology Letters, vol. 11, no. 5, pp. 499-515. http://dx.doi.org/10.1111/j.1461-0248.2008.01157.x. PMid:18294214.

ROSA, A.S., BLOCHTEIN, B. and LIMA, D.C., 2011. Potential honey bee contribution to canola pollination in southern Brazil. Scientia Agricola, vol. 68, no. 2, pp. 255-259. http://dx.doi. org/10.1590/S0103-90162011000200018.

SANTOS, A.B. and NASCIMENTO, F.S., 2011. Diversidade de visitantes florais e potenciais polinizadores de Solanum lycopersicum (Linnaeus) (Solanales: Solanaceae) em cultivos orgânicos e convencionais. Neotropical Biology and Conservation, vol. 6 , no. 3, pp. 162-169.

SANTOS, A.O.R., BARTELLI, B.F. and NOGUEIRA-FERREIRA, F.H., 2014. Potential pollinators of tomato, Lycopersicon esculentum (Solanaceae), in open crops and the effect of a solitary bee in fruit set and quality. Journal of Economic Entomology, vol. 107, no. 3, pp. 987-994. http://dx.doi.org/10.1603/EC13378. PMid:25026657.

SANTOS-NETO, O.D., KARSBURG, I.V. and YOSHITOME, M.Y., 2006. Viabilidade e germinabilidade polínica de populações de jurubeba (Solanum paniculatum L.) Revista de Ciências AgroAmbientais. Alta Floresta, vol. 4, no. 1, pp. 67-74.

SILVA, P.N., HRNCIR, M. and FONSECA, V.L.I., 2010. A Polinização por Vibração. Oecologia Australis, vol. 14, no. 1, pp. 140-151. http://dx.doi.org/10.4257/oeco.2010.1401.07.

SILVA-NETO, C., LIMA, F.G., GONÇALVES, B.B., LIMA, L.B., BERGAMINI, B.A.R., ELIAS, M.A.S. and FRANCESCHINELLI, E.V., 2013. Native bees pollinate tomato flowers and increase fruit production. Journal of Pollination Ecology, vol. 11, no. 6, pp. 41-45.
SILVEIRA, F.A., 2012 [viewed 03 May 2013]. Exomalopsini Michener, 1944. In: J.S. MOURE, D. URBAN and G.A.R. MELO, orgs. Catalogue of bees (Hymenoptera, Apoidea) in the Neotropical Region [online]. Curitiba: UFPR. Available from: http://www. moure.cria.org.br/catalogue.\%20Accessed\%20May/03/2013

STORTI, E.F., 1988. Floral biology of Solanum sessiliflorum Dun. var. sessiliflorum, in the Manaus region, AM. Acta Amazonica, vol. 18, no. 3-4, pp. 55-65. http://dx.doi.org/10.1590/180943921988183065 .

TEPPNER, H., 2005. Pollinators of tomato, Solanum lycopersicum (Solanaceae) in Central Europe. Phyton, vol. 45, no. 2, pp. 217.

VALLEJO-MARIN, M. and RAUSHER, M.D., 2007. The role of male flowers in andromonoecious species: energetic costs and siring success in Solanum carolinense L. Evolution; International Journal of Organic Evolution, vol. 61, no. 2, pp. 404-412. http:// dx.doi.org/10.1111/j.1558-5646.2007.00031.x. PMid:17348949.

VAN DER VALK, H., KOOMEN, I., NOCELLI, R.C.F., RIBEIRO, M.F., FREITAS, B.M., CARVALHO, S.M., KASINAMARTINS, D.J., MAINA, G., NGARUIYA, P., GIKUNGU, M., MUTISO, M.N., ODHIAMBO, C., KINUTHIA, W., KIPYAB, P., BLACQUIERA, T.,VAN DER STEEN, J., ROESSINK, I., WASSENBERG, J. and GEMMILL-HERREN, B., 2013. Aspect determining the risk of pesticides to wild bees: risk profiles for focal crops on three continents. Rome: FAO.

VEDDELER, D., OLSCHEWSKI, R., TSCHARNTKE, T. and KLEIN, A.M., 2008. The contribution of non managed social bees to coffee production: new insights based on farm-scale yield data. Agroforestry Systems, vol. 73, no. 2, pp. 109-114. http://dx.doi. org/10.1007/s 10457-008-9120-y.

WANIGASEKARA, R.W.M.U. and KARUNARATNE, W.A.I.P., 2012. Efficiency of buzzing bees in fruit set and seed set of Solanum violaceum in Sri Lanka. Psyche, vol. 7, pp. 1-7.

WINFREE, R., WILLIAMS, N.M., DUSHOFF, J. and KREMEN, C., 2007. Native bees provide insurance against ongoing honeybee losses. Ecology Letters, vol. 10, no. 11, pp. 1105-1113. http:// dx.doi.org/10.1111/j.1461-0248.2007.01110.x. PMid:17877737. 